\title{
The Effect of Cooperative Integrated Reading and Composition Technique on Students' Reading Descriptive Text Achievement
}

\author{
Zainuddin $^{1}$ \\ ${ }^{1}$ English and Literature Department, Faculty of Languages and Arts, Universitas Negeri Medan, Indonesia \\ Correspondence: Zainuddin, English and Literature Department, Faculty of Languages and Arts, Universitas \\ Negeri Medan, Jl. Willem Iskandar Pasar V, Kotak Pos No. 1589, Medan 20221, Indonesia. Tel: \\ 62-813-614-095-98. E-mail: zainuddin.gayo52@yahoo.com
}

Received: January 20, 2015 Accepted: February 26, 2015 Online Published: April 23, 2015

doi:10.5539/elt.v8n5p11 URL: http://dx.doi.org/10.5539/elt.v8n5p11

\begin{abstract}
This study was aimed at finding out the effectiveness of applying Cooperative Integrated Reading and Composition (CIRC) Technique on Students' Reading Descriptive Text Achievement. In other words, the objective of this study was to find out if there was a significant effect of applying Cooperative Integrated Reading and Composition (CIRC) Technique on Students' Achievement in Reading Descriptive Text. This study was designed with the experimental research. The subject of this research was the second year student of Junior High School in Indonesia. The subject consisted of 3 parallel classes. Every class consisted of 30 students. They were randomly selected out as the sample of the research, and divided into two equal groups, in which 30 students for experimental group and another 30 students for control group. The experimental group was taught by applying Cooperative Integrated Reading and Composition (CIRC) Technique, while control group was taught by using Classical Method (CM). The instrument of collecting data used objective test (multiple choice items) and subjective test for reading descriptive text materials. To obtain the reliability of the test, the researcher applied Kuder Richardson formula (KR. 21). The pre-test and post-test were administered and then the data were statistically analyzed by using the t-test formula. The result showed that the t-observed (4.539) was higher then t-critical value $(1.671)$ at the level of significance $(0.05)$ for $\alpha$-one tail test $(4.539>1.671)$, and the degree of freedom (df) was 58. Based on the analysis of the data, the result indicated that the null hypothesis (Ho) was rejected and the alternative hypothesis $(\mathrm{Ha})$ was accepted. It can be concluded that there was a significant effect of applying Cooperative Integrated Reading and Composition (CIRC) Technique on Students' Reading Descriptive Text Achievement compared with classical method (CM) of teaching.
\end{abstract}

Keywords: co-operative integreted reading composition, reading, and descriptive text

\section{Introduction}

\subsection{Background}

English language has been stated as a global language. It is said as a global language for its wider use as the language of science and technology. It has been a tool of communication in all over the world to communicate internationally. In Indonesia English is taught as a foreign language (EFL). It has been included in the school curriculum of Department of National Education and it is compulsory to study for all first, second as well as third class students of Junior High Schools (SMP) until Senior High Schools (SMA). The aim of teaching English as a Foreign Language in Indonesia is to enable the students to communicate meaningfully in speaking and writing skills (Departemen Pendidikan Nasional, 2007, p. 11).

In learning and teaching English as a foreign language in Indonesia the students are introducing the four basic skills of learning English, namely listening, speaking, reading, and writing. Since the position of English as a foreign language most of the students at the level of junior high schools, Sekolah Menengah Pertama (SMP) and senior high schools, Sekolah Menengah Atas (SMA) still find it difficult to study, especially for reading skill achievement of descriptive text. Based on the researcher's observation at the present time, the students' achievement is considered low in English fo reading skill in terms of lack of mastery learning grade of pasing grade minimum (KKM), known as Ketuntasan Kelulusan Minimum. Due to the difficulties faced by the students, the researcher attempted to overcome the students' problem by applying the appropriate of innovative approach which is developed by Slavin (1995) Cooperative Learning. Cooperative Integrated Reading and Composition 
(CIRC) technique in teaching reading skill. In respect to this approach Slavin (1995, p. 104) stated that Cooperative Integrated Reading and Composition (CIRC) is a comprehensive technique for teaching reading, writing and language arts in the upper elementary grades. It implies that CIRC Technique is quite relevant to apply in English Language Treaching for Junior High Schools (SMP Level) in Indonesia.

Reading is one of the four basic skills in teaching and learning English as a foreign language, beside listening, speaking and writing. According to Hartmann and Stork (1972, p. 192) Reading is the skill of recognizing and understanding written language in the form of sequences of graphic signs and its transformation into meaningfull speech, either as a silent comprehension or by reading aloud. The impilication is that reading is the skill of bringing meaning to and getting meaning from printed or written materials. According to Brown (2000, p. 185) Reading arguably the most essential skill for success in all educational context, remain a skill of paramount importance as we create assessment of general language ability.

In terms of current educational system in Indonesia, any teaching materials are designed on the basis of Competency-Based Curriculum 2005 (known as Kurikulum Berbasis Kompetensi 2005 or KBK for short), and today, the implementation of the curriculum development is based on the Unit Level Curriculum of Education 2007 (known as Kurikulum Tingkat Satuan Pendidikan 2007 or KTSP for short). Based on the implementation of the curriculum model KTSP, the teaching materials should be developed and contextually determined on the basic competence, standard competence, and some indicators, which are organized as the setting in the lesson plan. It is indicating that the students are expected to be able to achieve the aims of teaching and learning process in terms of mastery learning (known as "belajar tuntas") for interpersonal and transactional function of written text. The text types or (genre) used in the Junior High Schools (SMP) curriculum are narrative, descriptive, recount, and anecdote for the second year students. This research was conducted at the second year students of Junior High School (SMP) in Indonesia. This research used a reading descriptive text to be taught on the students' achievement by applying Cooperative Integrated Reading and Composition (CIRC). CIRC is one of the most effective of the cooperative learning methods in reading, writing and language arts (Slavin, 1995, p. 109).

By reading different types of simple and short written text especially a reading descriptive text of genre the students were introduced the social function of the short written text, such as describing a particular person, place or thing. In edition, reading a descriptive text the students will be able to understand the meanings carried out in the text and get more information about language features that may found through the text, such as generic structure: identifying parts, qualities and characteristics, and lexico-grammatical features (language features): identifying participants, noun, adjective, and simple present tense. Selected materials of reading texts can motivate the students to study a language, especially for language skills.

The English teachers should realize what are the main problems they might face in their teaching presentation. Viewed from the teaching point of view, the teacher should be able to organize a good teaching materials as the facilitator and make the class always interesting, and viewed from the learning point of view the teacher should be able to have an effective and appropriate teaching method or technique in their teaching presentation in order to motivate the students in the teaching presentation. In this case there are two questions to take into consideration what to teach? And how to teach? What to teach deals with the teaching materials and, How to teach deals with the teaching method or technique. Actually the main aim of teaching reading is to develop the students' achievement to comprehend the information and the meaning carried out from the reading text.

Based on the researcher's experience during the time of research observation in teaching practice at the second year students of the State Junior high school (SMP), the researcher found the mean problems on the students' reading skill achievement was that, the use of an appropriate teaching method, and another problem was concerned much with uninteresting teaching reading materials, rather than selected the relevance of genre reading text. Hence, the impact was directly lacking on the student's achievement in reading descriptive text.

Based on the above teaching situation, it is needed to select the teaching reading materials and the most innovation teaching method, in order to encourage the student's motivation for reading lesson especially for reading descriptive text. Thus, this research attempts to select the teaching materials by using a reading descriptive text and applying an appropriate teaching technique that is Cooperative Integrated Reading and Composition (CIRC) Technique. This technique is considered the most effective and appropriate one for teaching students achievement in reading descriptive text. CIRC is derived from cooperative learning which facilities the students to comprehend the reading text given more easily. The students are taught to work together within the groups to achieve the goal of reading descriptive text. Slavin (1995), stated that CIRC the students are divided into several teams from the different reading groups. A team consists of pairs of students. For example a team consists of two students from high reading group and two students from the low reading group. Students work in 
pairs within their teams on a series of cognitively engaging activities, including partner reading (reading to each other), making prediction, identification of characters, settings, problem solutions, summarization, vocabulary, reading comprehension exercises and story related writing.

\subsection{Research Question}

Based on the background of the study, the research problem is formulated in the form of a question as the following:

"Is there significant effect of Cooperative Integrated Reading and Composition (CIRC) Technique on Students' Reading Descriptive Text Achievement?"

\subsection{The Objective of the Study}

In line to the research problem stated above, the objectives of this study is about to investigate and to find out if Cooperative Integrated Reading and Composition (CIRC) Technique significantly affects the students' reading descriptive text achievement of the second year students of Junior High School (SMP).

\subsection{The Scope of the Study}

The scope of the study is focused on the text type or genre of reading descriptive text. Descriptive text is one of the text types in the area of English language teaching reading skill, such as narrative, exposition, recount, and procedure (Departemen Pendidikan Nasional Model Silabus Mata Pelajaran Bahasa Inggris SMP/MTS 2007). Respectiply, the study applied the CIRC technique in teaching reading descriptive text on the second year students' acchievement of Junior High School.

\subsection{The Significance of the Study}

The findings of this study are expected to give some contributions to:

1) The English teachers that Cooperative Integrated Reading and Composition (CIRC) Technique providing students with an incentive and more effective and efficient to help each other within the group. The only by choosing appropriate approach of teaching the English teachers will have a particular success in their teaching presentation,

2) The English language learners, to have a better learning strategy or technique on the students' reading descriptive text,

3) Those who are motivated in applying Cooperative Integrated Reading and Composition (CIRC) Technique in conducting the same research problem,

4) Provide the following researchers' knowledge and information in applying an innovative approach in terms of appropriate English lamguage teaching technique as a foreign or second language teaching for different use of genres text.

\section{Literature Review}

\subsection{The Achievement}

The term achievement has something to do with the learning activities and the test over a longer period of learning. According to Brown (2001, p. 391) an achievement test is related directly to classroom lessons, unit, or even a total curriculum. Achievement test can serve as indicators of features that a student need to work on in the future, but the primary role of an achievement test is to determine acquisition of course objectives at the end of a period of instruction.

Traves $(1970$, p. 447) stated that achievement is the result of what an individual has learned from some educational experiences. The definition of achievement as the progress pupils make toward the goals and objectives of the curriculum, they then assert further about the definition that achievement may be the one's ability or the extent of his/her knowledge in a specific content area (http://www.hmsofyanisnianspd.blogspot. com).

Reffering to the opinions pressented above it can be stated that achievement is the result, the successfulness, the extent or ability, the progress in learning educational experiences that the individual indicates it in relation with his/her educational learning.

\subsection{Reading}

Grabe and Stoller (2002, p. 9) stated that reading is the ability to draw meaning from printed and interpret this information appropriately. Reading is a complex behavior, which involves conscious and unconscious use of various strategies, including problems solving strategies, to build a model of the meaning, which the writer is 
assumed to have intended. The following Grabe and Stoller (2002, p. 4) also stated that reading can be though of as a way to draw information from a text and to form an interpretation of that information. The ideas expressing in this context reading is the process of interpreting meaning and information from prented materials in terms of using strategies to solve some problems. Heilman et al. (1981, p. 4) stated that reading is a product of interesting with the printed language should be comprehend. This simple definition implies that reading is an activity to have the outcome of comprehending the meaning from the printed or written language. Cline et al. (2006, p. 2) said that reading is decoding and understanding written text. Decoding requires translating the symbol of writing system into the spoken words which they represent. Understanding is determined by the purposes for reading, the context, the nature of the text, and the readers' strategies and knowledge. The ideas carried out in this context reading is concerned with the sign interpretation and determining the objectives of reading from context of the text

\subsection{Descriptive Text}

Descriptive text is a text, which says what a person or a thing is like. Its purpose is to describe and reveal a particular person, place, or thing (http://understandingtext.blogspot.com). Other virson about ddescriptive text is a text which presents information about something specifically. The purpose of descriptive text: to describe a particular person or thing or place specifically. For example, The Generic Structure of descriptive text: 1) identification: introduce a particular person or thing or place, 2) Description: describing physical appearance, quality, behavior, etc. (http://surviverenglish.blogspot.com). Gerot and Wignel (1994, p. 208) also emphesized that the term description is concerned with the aspect of describing a particular person, place or thing in social function of the text.

From the three view points presented above it can be stated that the concept of descriptive text focused on describing information about specific thing in the text. The specific thing possibly deals with describing a physical performance of different objects such as personality, places, event or any other things that one who admirers.

In relation to the idea of descriptive text, Wishon and Burks (1980, p. 379) said that, Description produces the way things look, smell, taste, feel or sound it may also evoke moods, such as happiness, loneliness, or fear. It is used to create a visual image of peole, places, even of units of time days, times of day, or seasons. It may be used also to describe more than the outward appearance of people. It may tell about their traits of character or personality. Referring to the idea presented, it is to state that more different things would be described phisycally performanced, such as feeling of happiness or might be unhappiness and possibly sadness.

\subsection{Cooperative Integrated Reading and Composition}

CIRC technique is developed to support traditionally used "skill-based reading groups" approach. Firstly, reading groups are established in the classroom. Next, students are paired off within the groups. When the teacher works with a reading group, couples try to teach each other meaningful reading and writing skills by using reciprocal learning technique. They help each other in performing basic skill-building activities (such as oral reading, contextual guessing, asking questions, summarizing, writing a composition based on the story, revising-correcting composition) (Durukan in Academic Journal, 2010, p. 2).

According to Slavin (1995, pp. 105-106) one major focus of the CIRC activities prescribed for basal stories is on making more effectiveness use of follow-up time: Students work within cooperative teams on these activities, which are coordinated with reading-group instruction, in order to meet objectives in such areas as reading comprehension, vocabulary, decoding, and spelling. Students are motivated to work with one another on these activities by the use of a cooperative reward structure in which they may earn certificates or other recognition based on the learning of all team members.

1) Oral Reading, reading out loud is a standard part of most reading programs. One objective of the CIRC program is to greatly increase students' opportunities to read aloud and receive feedback on their reading by having students read to teammates and by training them in how to respond to one another's reading.

2) Reading Comprehension Skills, studies of good and poor readers have consistently found that poor readers lack comprehension strategies and metacognitive control of their reading, and that these strategic deficits play a large part in their comprehension problems. A major objective of CIRC is to use cooperative teams to help students learn broadly applicable reading comprehension skills. The students in CIRC also make and explain predictions about how problems will be resolved and summarize main elements of stories to one another, both of which are activities found to increase reading comprehension.

3) Writing and Language Arts, a major objective of the developers of the CIRC writing and language arts 
program was to design, implement, and evaluate a writing-process approach to writing and language arts that would make extensive use of peers.

\subsection{Hypothesis}

The hypothesis of this research can be formulated in terms of (Ha and Ho)._Ha- means alternative hypothesis and Ho- means null hypothesis.

Ho: There is no significant effect of applying classical method (CM) on students' reading descriptive text achievement.

Ha: There is significant effect of applying Cooperative Integrated Reading and Composition (CIRC) technique on students' reading descriptive text.

\section{Methodology}

\subsection{Research Design}

This study was designed in experimental research. In experimental research there are two different groups of treatment, namely experimental group and control group. In experimental group the students were taught by using Cooperative Integrated Reading and Composition (CIRC) technique, while in the control group the students were taught by applying classical method (CM). The two groups were given pre- test and post- test. Pretest was given before treatment, and post-test was trated after the process of class treatment. Pretest and posttest data was administered in terms of comparing the groups (experimental and control) for measuring change resulting from experimental treatments. The design of the research can be seen in the following table.

Table 1. The design of the research

\begin{tabular}{llll}
\hline Group & Pre-test & Treatment & Post-test \\
\hline Experimental & $\sqrt{ }$ & Using Cooperative Integrated Reading and & $\sqrt{ }$ \\
Control & $\sqrt{ }$ & Composition (CIRC) Technique. & $\sqrt{ }$ \\
\hline
\end{tabular}

\subsection{Subjects and Sample}

Best (2002, p. 13) said that population is any group of individuals, which have one or more characteristics in common. In this research the researhcer tends to use subject instead of the term population. The subjects are those of three parallel classes of the second year students or grade II of Junior High School (SMP). Every class consisted of 30 students. So the total number of the subject was 90 students. The subject is considered too big to conduct the research, in terms of the effectiveness and efficiency of the teaching presentation. Hence, the researcher used random sampling technique for selecting a sample, Gay (1987, p. 108) stated that random sampling is the process of selecting a sample in such a way that all individuals in defined population have an equal and independent chance of being selected for the sample. Therefore, there were 60 students became the sample of the research. The total number of the students were devided into two groups, namely 30 student for experimental group and another 30 for control group.

\subsection{Research Instrument}

The instrument for collecting data used objective test (multiple choice items) and subjective test for reading desccriptive text Groundlund (1985, p. 152), stated that multiple choice test format has two major advantages for course such as test is designed to measure the recall understanding and applying of specific concepts, or principles because the students can answer a large number of such questions in a short time, a large sample of items can be incorporated into the test.

In this research, there were 20 items of objective tests were designed in terms of reading descriptive text and 10 items the students required to give the answer in written form based on the information from reading descriptive text (see appendix as an example).

\subsection{Technique of Collecting Data}

The technique of collecting data through out the result of Pre-Test and Post-Test which had been administered before and after treatment of the two groups namely experimental and control groups. The result of Pre-Test refers to the homogeneity of the sample if the two groups are relatively equal in reading achievement. While the 
result of Post-Test refers to the interpretation of the effects of CIRC Technique compared with classical method. In other words, to investigate the students' achievement of indipendent variables of technique affect the dependent variable (to be observed).

\subsection{The Research Procedures}

The procedures of the research were designed into four steps namely, pre-test, treatment, post-test, and scoring the test by using statistical analysis. The role of statistical analysis in this case is that, to answer the previous question purposed of the study.

\subsubsection{Pretest-Posttest}

Dimitrov and Rumrill (2003) stated that pretest-posttest designs are widely used in behavioral research, primarily for the purpose of comparing groups and/or measuring change resulting from experimental treatments. In this research the pretest and posttest data was comparing between experimental groups and control groups. Experimental group was taught by applying cooperative integrated reading and composition (CIRC) technique,n and control group was taught by using classical method (CM). Crosswell $(2012$, p. 293) said that a pretest provided a measure on some atributes or characteristics that you access for participant in an experiment before they receive a treatment. In other words, pretest is primarily done before the class treatment and posttest treated after following the class treatment. The pre-test is given both for experimental and control groups to find out the homogeneity of the students' reading descriptive text achievement. The result of the test was administered and compared between two groups if they were in the same level of the reading achievement using descriptive text.

\subsubsection{Treatment}

In experiments, a treatment is something that researchers administer to experimental units, for example a teacher practices different teaching methods on different groups in her class to see which yields the best results (http://www.stat.yale.edu). In this research the two groups used different teaching methods for the second year students (grade II) of Junior High School (SMP). For experimental group used Cooperative Integrated Reading and Composition (CIRC) technique on the students' reading achievement and for the control group used classical method $(\mathrm{CM})$ on the students' reading achievement.

The treatment of the two classes organized of six class meetings, both in experiment and control groups. The reading materials are treated the same to both groups of the class teaching presentation, in terms of posttest performance.

\subsubsection{Scoring the Test and Statistical Analysis}

Kusumo, et.al (1987, p. 6) stated that scoring of the test deals with the marking point of view, test could be divided into objective and subjective (essay) test. In the objective test we have only one answer but in a subjective (essay) test we can have different possible answers. In this research used objective test and subjective test on the students' reading descriptive text of the second year students of Junior High School (SMP). The statistical approach used Kurder Ricardson (KR 21) (Bachman, 1990, p. 176).

\section{Findings and Discussion}

\subsection{Findings}

In this part provides the means score achievement in terms of standard deviations (SD) for both experimental group, and control group. The two groups were given the same test, pre-test and post-test on the students' reading descriptive text achievement. The number of the test items: objective test $=20$ items and essay test $=10$ items. The total number of the test items is 30 . In other words, two sets of variables the means of SD score which was deal with. The means score of SD for experimental as the effect independent variable to be tasted and cause dependent variabel of descriptive text.

The total scores of experimental group in pre-test $(\Sigma X)=1565$ and the total scores of experimental group in post-test $\left(\Sigma \mathrm{X}_{1}\right)=2109$ (see Appendix I). The total scores of control group in pre-test $(\Sigma \mathrm{Y})=1342$ and the total scores of control group in post-test $\left(\Sigma Y_{1}\right)=1566$ (see Appendix II). Based on the criteria of achievement, in pre-test, 16 students of experimental group $(53.33 \%)$ were failed, 9 students $(30 \%)$ were poor, 5 students $(16.66 \%)$ were fair, and no student $(0 \%)$ was good; in post-test, no student $(0 \%)$ were failed, 3 students $(10 \%)$ were poor, 13 students $(43.33 \%)$ were fair, 10 students $(33.33 \%)$ were good, and 4 students $(13.33 \%)$ were excellent. In pre-test, 25 students in control group (66.66\%) were failed, 3 students $(10 \%)$ were poor, 2 students $(6.67 \%)$ were fair, no student $(0 \%)$ was good, and no student $(0 \%)$ was excellent. In post-test, 15 students $(50 \%)$ were failed, 11 students $(36.66 \%)$ were poor, 3 students $(10 \%)$ were fair, 1 student $(3.33 \%)$ was good, and No student $(0 \%)$ was excellent. The mean of experimental group $\left(\mathrm{M}_{E X}\right)=70.13$, and the standard deviation $\left(\mathrm{SD}_{E X}\right)=$ 
60. Then, the mean of control group $\mathrm{M}_{C O N}=52.20$, and the standard deviation $\left(\mathrm{SD}_{C O N}\right)=21.60$.

\subsubsection{Statistical Analysis}

\subsubsection{The Reliability of Means Score (SD)}

The following analysis showing the means score of SD of the students' reading descriptive text achievement in two different tests, namely objective test and essay test.

The Reliability of Objective test:

The Reliability of Essay test:

$k_{O}$ (number of test items) $=20$

$k_{E}=10$

$\mathrm{M}_{E X}=70.13$

$\mathrm{M}_{E X}=70.13$

$\mathrm{SD}_{E X}=60$

$\mathrm{SD}_{E X}=60$

$\mathrm{r}=\frac{k}{k-1}\left[1-\frac{M(k-M)}{k \cdot S D^{2}{ }_{E X}}\right]$

$\mathrm{r}=\frac{k}{k-1}\left[1-\frac{M(k-M)}{k \cdot S D_{E X}^{2}}\right]$

$\mathrm{r}=\frac{20}{20-1}\left[1-\frac{70.13(20-70.13)}{20.60^{2}}\right]$

$\mathrm{r}=\frac{10}{10-1}\left[1-\frac{70.13(10-70.13)}{10.60^{2}}\right]$

$r=\frac{20}{19}\left[1-\frac{70.13(50.13)}{20 \times 3.600}\right]$

$\mathrm{r}=\frac{10}{9}\left[1-\frac{70.13(701.3)}{10 \times 3.600}\right]$

$r=\frac{20}{19}\left[1-\frac{3515.61}{72.000}\right]$

$r=\frac{10}{9}\left[1-\frac{49182.16}{36.000}\right]$

$\mathrm{r}=\frac{20}{19}[1-0.04]$

$r=\frac{10}{9}[1-1.36]$

$\mathrm{r}=\frac{20}{19} \mathrm{X} 0.96$

$r=\frac{10}{9} \times 0.36$

$\mathrm{r}=1.01$

$r=0.4$

$\mathrm{r}=1$

Total reliability $=\frac{\text { reliability of objective }+ \text { reliability of essay }}{2}$

Total reliability $=\frac{1+0.4}{2}$

Total reliability $=0.7$

The reliability of the test is sufficient. It means that the test is reliable

4.1.1.2 The Analysing the Data Using T-Test

Experimental group as an independent variable using cooperative Integrated Reading and Composition (CIRC) technique affects significantly on the students' reading descriptive text achievement by applying the t-test formula as the following.

$$
\begin{array}{ll}
\mathrm{M}_{E X}=70.13 & \mathrm{~N}_{E X}=30 \\
\mathrm{M}_{C O N}=52.20 & \mathrm{~N}_{C O N}=30 \\
\Sigma d_{x} 1=12321 & \Sigma d_{y} 1=2832
\end{array}
$$

$\mathrm{t}=$

$$
\frac{M_{E X}-M_{C O N}}{\sqrt{\left(\frac{\Sigma d x 1+\Sigma d y 1}{N_{E X}+N_{C O N}-2}\right)\left(\frac{1}{30}+\frac{1}{30}\right)}}
$$

$\mathrm{t}=$

$$
\frac{70.13-52.20}{\sqrt{\left(\frac{12321+2832}{30+30-2}\right)\left(\frac{1}{30}+\frac{1}{30}\right)}}
$$




$$
\begin{aligned}
& t=\frac{17.93}{\sqrt{(261.25)(0.06)}} \\
& t=\frac{17.93}{\sqrt{15.65}} \\
& t=\frac{17.93}{3.95} \\
& t=4.539
\end{aligned}
$$

\subsubsection{Testing Hypothesis}

Based on the previous analysis, it was found the value of t-observer (4.539) was higher than the value of $t$-table $(1.671)$ at the level of significant $(0.05)$ for $\alpha$-one tail test $(4.539>1.671)$ and the degree of freedom (df) was 58 . Hence, the null hypothesis has been successfully rejected. It is indicating that Cooperative Integrated Reading and Composition (CIRC) technique significantly affects the students' reading descriptive text achievement of the second year students of SMP.

\subsection{Discussion}

Referring to the previous analysis and disscussion, the research findings tend to show the eksperimental group is dominant in case of having means score of standard deviation (SD), achievement, compared with control group. Evidently, the total scores of experimental group in pre-test $(\Sigma X)=1565$ and the total scores of experimental group in post-test $\left(\Sigma X_{1}\right)=2109$. It means that the score of experimental group is sharply increased 510 point $(32.58 \%)$. The total scores of control group in pre-test $(\Sigma Y)=1342$ and total scores of control group in post-test $\left(\Sigma Y_{1}\right)=1566$. It indicates that the score of control group is increased 225 points $(16.69 \%)$.

Research findings also tend to show that eksperimental group is dominantly higher in obtaining the reliable score achievement using $t$-test table distribution. Evidently, eksperiment group cooperative integrated reading and composition (CIRC) technique, revealed that the t-observed (4.539) is higher than t-critical review (1.671) which is taught by applying classical method (CM), or it can be interpreted (t-observed $4.539>\mathrm{t}$-critical review 1.671).

From the findings and referring to the previous research question and the hypothesis proposed, it is evidently proved that the Cooperative Integrated Reading and Composition (CIRC) technique, significantly affects the students' achievement in reading descriptive text of the second year students (grade II) of Junior High School (SMP).

\section{Conclusion}

After analyzing the data of this research, it tends to deal with two mains different aspects of the students' reading descriptive text achievement of the second year students grade II of Junior High School (SMP) The two different aspects is that, scoring achievement of standart deviation (SD) and reliable score achievement of experiment and control group.

The SD score achievement of experimental group in pre-test $(\Sigma X)=1565$ and the total scores of experimental group in post-test $\left(\Sigma X_{1}\right)=2109$. It reveals that the score of experimental group is increased 510 point (32.58\%). The total scores of control group in pre-test $(\Sigma Y)=1342$ and total scores of control group in post-test $\left(\Sigma Y_{1}\right)=$ 1566. It indicates that the SD score of control group is increased 225 pints $(16.69 \%)$. It can be interpreted that experimental group of SD achievement is dominant one compared with control group, either pretest or post test achievement.

From the view points of reliable score achievement the students who taught by applying (CIRC) technique, got the higher achievement compared with those who taught by using classical method (CM). In evidence, eksperiment group, cooperative integrated reading and composition (CIRC) technique, shows that t-observed (4.539) is higher than t-critical review (1.671) which is taught by applying classical method (CM), or in terms of comparing the two groups achievement (t-observed $4.539>\mathrm{t}$-critical review 1.671).

Therefore, it can be concluded that Cooperative Integrated Reading and Composition (CIRC) technique significantly affects the students' descriptive text reading achievement compared with classical method (CM).

\section{References}

Bachman, L. F. (1990). Fundamental Consideration in Language Text. New York: Oxford University Press.

Best, J. W. (2002). Research in Education. New York: Prentice-Hall. 
Brown, H. D. (2000). Principles of Language Learning and Teaching. New York: Logman.

Brown, H. D. (2001). Teaching by Principles an Interactive Approach to Language Pedagogy (2nd Ed.). New York: Logman.

Burns and Olson. (1984). Teaching Reading in Today's Elementary School. Knoxville: University of Tenesse.

Cline et al. (2006). Focus group reactions to three definitions of reading (as originally developed in support of NARAP goal 1). Minneapolis, MN: National Accessible Reading Assessment Projects.

Crosswell, J. W. (2012). Educational Research: Planning, Conducting and Evaluating Quantitative and Qualitative Research. Boston: Pearson Education.

Departemen Pendidikan Nasional. (2007). Model Silabus dan Rencana Pelaksanaan Pembelajaran. Mata Pelajaran: Bahasa Inggris SMP/MTS: BSNP. Jakarta.

Dimitrov, D. M., \& Philip, D. R. Jr. (2003). Pretest-Posttest Design and Measurement of Change. Speaking of Research. Work, 20, 159-165.

Durukan, E. (2010). Effects of Coopertaive Integrated Reading and Composition (CIRC) technique on Reading-Writing Skills. Academic Journal, 6(1), 102-109.

Gay, L. (1987). Educational Research: Composition. Cambridge: Winthrop.

Gerot, L., \& Peter, W. (1994). Making Sense of Functional Grammar. Australia: Greed Stabler.

Grabe, W., \& Stoller, F. (2002). Teaching and Researching Reading. Harlow: Pearson Education Limited.

Grounlund, N. E. (1985). Measurement and Evaluation in Teaching. New York: Prentice-Hall.

Hartman and Stork. (1973). Dictionary of Language and Linguistics. London: Applied Science Publisher.

Kusumo et al. (1987). Materi Pokok Pengelolaan Pengajaran Bahasa Inggris II. Jakarta: Karunika Universitas Terbuka.

Slavin, R. E. (1995). Cooperative Learning: Theory, Research, and Practice. Englewood Cliffs, New Jersey: Prentice-Hall.

Travers, J. P. (1970). Fundamentals of Educational Psychology. Scrantom, Pensylvania: International Textbook Company.

Wishon, G. E., \& Julia, M. B. (1980). Let's Write English. New York: Liton Educational Publishing Internasional.

\section{Appendix 1}

The scores of experimental group

\begin{tabular}{llllllll}
\hline \multirow{2}{*}{ No. } & \multirow{2}{*}{ Initial Names } & Pre-test & \multicolumn{5}{l}{ Post-test } \\
\cline { 3 - 8 } & & Objective & Essay & Score & Objective & Essay & Score \\
\hline 1. & WD & 60 & 36 & 48 & 80 & 64 & 72 \\
2. & AO & 50 & 36 & 43 & 60 & 58 & 59 \\
3. & MRF & 65 & 52 & 59 & 80 & 74 & 77 \\
4. & AA & 60 & 30 & 45 & 60 & 76 & 68 \\
5. & EY & 50 & 52 & 51 & 60 & 74 & 67 \\
6. & TAS & 45 & 44 & 45 & 75 & 68 & 71 \\
7. & MH & 60 & 52 & 56 & 85 & 88 & 86 \\
8. & SKS & 65 & 44 & 55 & 70 & 66 & 68 \\
9. & ADP & 30 & 52 & 41 & 70 & 64 & 67 \\
10. & FH & 45 & 37 & 41 & 60 & 74 & 67 \\
11. & YR & 50 & 44 & 47 & 75 & 68 & 71 \\
12. & ID & 30 & 66 & 48 & 60 & 76 & 68 \\
\hline
\end{tabular}




\begin{tabular}{llllllll}
\hline 13. & SN & 60 & 56 & 58 & 75 & 68 & 71 \\
14. & FD & 65 & 52 & 59 & 90 & 86 & 88 \\
15. & MF & 65 & 52 & 60 & 85 & 76 & 81 \\
16. & YD & 70 & 44 & 57 & 90 & 74 & 82 \\
17. & RE & 45 & 62 & 54 & 65 & 76 & 70 \\
18. & ADT & 50 & 46 & 48 & 75 & 68 & 72 \\
19. & YH & 50 & 55 & 53 & 80 & 76 & 78 \\
20. & MFN & 60 & 52 & 56 & 70 & 58 & 64 \\
21. & YWA & 60 & 46 & 53 & 60 & 58 & 59 \\
22. & MBS & 60 & 64 & 62 & 70 & 60 & 65 \\
23. & DT & 65 & 64 & 65 & 60 & 74 & 67 \\
24. & TA & 45 & 52 & 49 & 60 & 58 & 59 \\
25. & REP & 50 & 46 & 48 & 60 & 68 & 64 \\
26. & LS & 50 & 44 & 47 & 70 & 66 & 68 \\
27. & SK & 70 & 62 & 69 & 85 & 56 & 70 \\
28. & ONG & 65 & 62 & 64 & 70 & 68 & 69 \\
29. & AD & 60 & 20 & 40 & 75 & 60 & 68 \\
30. & KS & 40 & 48 & 44 & 70 & 75 & 73 \\
\hline & Total: & 1575 & 1472 & $\Sigma X=1565$ & 2145 & 2075 & $\Sigma X_{1}=2109$ \\
\hline
\end{tabular}

$\Sigma X_{1}-\Sigma X=2075-1565=510$

It means that the scores of Experimental Group are increased 510 point or $32.58 \%$.

$$
\begin{array}{lll}
\mathrm{M}_{E X}=\frac{\Sigma \mathrm{X} 1}{\mathrm{~N}} & \mathrm{SD}_{E X}=\sqrt[3]{\frac{\Sigma d x 1}{N}} & \mathrm{SD}_{E X}=3 \times 20=60 \\
\mathrm{M}_{E X}=\frac{2104}{30} & \mathrm{SD}_{E X}=\sqrt[3]{\frac{12321}{30}} \\
\mathrm{M}_{E X}=70.13 & \mathrm{SD}_{E X}=\sqrt[3]{410.7} &
\end{array}
$$

\section{Appendix 2}

The scores of control group

\begin{tabular}{llllllll}
\hline \multirow{2}{*}{ No. } & \multirow{2}{*}{ Initial Names } & \multicolumn{2}{l}{ Pre-test } & \multicolumn{5}{l}{ Post-test } \\
\cline { 3 - 8 } & & Objective & Essay & Score & Objective & Essay & Score \\
\hline 1. & RR & 40 & 36 & 38 & 60 & 58 & 59 \\
2. & PH & 35 & 42 & 38 & 45 & 56 & 51 \\
3. & FMS & 50 & 44 & 47 & 50 & 46 & 48 \\
4. & SR & 55 & 34 & 44 & 65 & 38 & 52 \\
5. & BTR & 55 & 46 & 50 & 70 & 66 & 68 \\
6. & BP & 30 & 46 & 38 & 45 & 56 & 51 \\
7. & KS & 40 & 32 & 36 & 50 & 46 & 48 \\
8. & RAP & 45 & 36 & 40 & 45 & 46 & 46 \\
9. & SF & 40 & 34 & 37 & 50 & 42 & 46 \\
\hline
\end{tabular}




\begin{tabular}{llllllll}
\hline 10. & DA & 40 & 34 & 37 & 40 & 36 & 38 \\
11. & MI & 55 & 44 & 49 & 65 & 47 & 56 \\
12. & TH & 65 & 46 & 55 & 65 & 50 & 58 \\
13. & THA & 45 & 34 & 40 & 60 & 76 & 68 \\
14. & IB & 55 & 42 & 48 & 60 & 44 & 52 \\
15. & TF & 40 & 32 & 36 & 45 & 42 & 44 \\
16. & MYS & 45 & 34 & 39 & 50 & 46 & 48 \\
17. & ND & 50 & 42 & 46 & 55 & 46 & 51 \\
18. & DA & 55 & 34 & 44 & 60 & 44 & 52 \\
19. & SY & 50 & 44 & 47 & 55 & 42 & 49 \\
20. & LA & 40 & 34 & 37 & 50 & 48 & 49 \\
21. & CM & 45 & 46 & 46 & 50 & 42 & 46 \\
22. & SD & 45 & 34 & 39 & 45 & 42 & 44 \\
23. & ES & 70 & 62 & 66 & 70 & 66 & 68 \\
24. & MK & 60 & 52 & 56 & 60 & 56 & 58 \\
25. & LA & 50 & 46 & 48 & 55 & 42 & 49 \\
26. & AAT & 55 & 34 & 45 & 50 & 48 & 49 \\
27. & AL & 50 & 42 & 46 & 50 & 46 & 48 \\
28. & DW & 70 & 60 & 65 & 85 & 56 & 71 \\
29. & RM & 50 & 46 & 48 & 60 & 44 & 52 \\
30. & HS & 40 & 34 & 37 & 50 & 44 & 47 \\
\hline & Total: & 1465 & 1226 & $\Sigma Y=1342$ & 1660 & 1461 & $\Sigma d Y_{1}=1566$ \\
\hline
\end{tabular}

$\Sigma d Y_{1}-\Sigma Y=1566-1342=224$

It means that the scores of Control Group are increased 224 point or $16.69 \%$.

$$
\begin{array}{lll}
\mathrm{M}_{C O N}=\frac{\Sigma Y_{1}}{\mathrm{~N}} & \mathrm{SD}_{C O N}=\sqrt[3]{\frac{\Sigma d Y 1}{N}} & \mathrm{SD}_{C O N}=3 \times 7.2=21.6 \\
\mathrm{M}_{C O N}=\frac{1566}{30} & \mathrm{SD}_{C O N}=\sqrt[3]{\frac{1566}{30}} & \\
\mathrm{M}_{C O N}=52.20 & \mathrm{SD}_{C O N}=\sqrt[3]{52.2} 0 &
\end{array}
$$

\section{Copyrights}

Copyright for this article is retained by the author(s), with first publication rights granted to the journal.

This is an open-access article distributed under the terms and conditions of the Creative Commons Attribution license (http://creativecommons.org/licenses/by/3.0/). 